\title{
PATTERNS OF FISH SPECIES RICHNESS IN RIVERS OF THE CENTRAL REGION OF ARGENTINA
}

\author{
BISTONI, M. A. and HUED, A. C. \\ Cátedra de Diversidad Animal II, Facultad de Ciencias Exactas, Físicas y Naturales, \\ Universidad Nacional de Córdoba, Av. Vélez Sársfield, 299, 5000 Córdoba, Argentina \\ Correspondence to: María de los Ángeles Bistoni, Facultad de Ciencias Exactas, Físicas y Naturales, Universidad \\ Nacional de Córdoba, Av. Vélez Sársfield, 299, 5000 Córdoba, Argentina, e-mail: mbistoni@ com.uncor.edu \\ Received July 30, 2001 - Accepted January 18, 2002 - Distributed November 30, 2002
}

(With 2 figures)

\begin{abstract}
We analyzed the variation of fish species richness and trophic structure along an upstream-downstream gradient and identified the factors associated with the pattern observed. The fish community composition varied along a headwater-downstream gradient. Species richness and trophic structure decreased significantly with increasing altitude and increased with stream order and distance from source. Headwater communities showed a simple structure. Oncorhynchus mykiss was the only fish captured or noticeably dominant at high altitudes. Thus, headwater can be classified as "trout zones". From these zones to downstream areas fish communities changed because of the addition of other fish species. This phenomenon probably occurs because of an increase in habitat diversity.
\end{abstract}

Key words: fish species richness, rivers, altitude, distance from source, order.

\section{RESUMO}

Padrões de riqueza de espécies ícticas em rios da região central da Argentina

O presente trabalho teve por objetivo analisar a variação da riqueza de espécies ícticas e da estrutura trófica das comunidades do gradiente nascente-desembocadura, nos rios da região central da Argentina, e identificar os fatores associados ao padrão observado. A composição da comunidade íctica variou desde as cabeceiras até a desembocadura dos sistemas lóticos considerados. A riqueza e a estrutura trófica se relacionaram significativamente com a altitude, a ordem e a distância da origem. As comunidades de cabeceira apresentaram estrutura simples. Oncorhynchus mykiss foi a única espécie capturada ou claramente dominante nas maiores altitudes. Assim, as zonas de nascentes podem ser classificadas como "zonas de trutas". Desde estas zonas até a desembocadura, as comunidades de peixes mudaram devido à adição de novas espécies. Esse fenômeno provavelmente se deve ao incremento da diversidade de habitat e à maior estabilidade ambiental que caracteriza as zonas baixas dos cursos.

Palavras-chave: riqueza de espécies ícticas, rios, altitude, distância da origem, ordem.

\section{INTRODUCTION}

Most river systems on Earth arise from small headwater streams and increase longitudinally in size, discharge and a large number of related physical and biological parameters. In most streams, there is a progressive increase in number of fish species downstream (Horwitz, 1978) and numerous other species-specific (e.g. growth rates, abundance) or assemblage-specific (e.g. diversity, biomass) variables change trenchantly from headwater to downstreams.

Several studies have analyzed the fish community structure along an upstreamdownstream gradient in order to predict species richness based on measurements such as altitude, order, stream gradient, distance from source (Platts, 1979; Beecher et al., 1988; Oberdorff \& Porcher, 1992). These abiotic factors can influence not only species richness but also trophic composition 
(Schlosser, 1982; Angermeier \& Karr, 1983). In many studies, the number of species increased downstream with a marked difference in species richness between the headwater and downstream zones. These patterns of community structure have been attributed to two complementary processes that occur at different spatial scales: biotic zonation and continuous addition of species (Rahel \& Hubert, 1991).

Biotic zonation refers to communities distributed along a stream as a result of discontinuity in geomorphology or temperature (Hawkes, 1975). These biotic zones provide a useful basis to classify different sections of a river, named after the dominant fish species in each zone.

Species addition is defined as an increase in the community complexity due to the presence of new species. New species are added because of the increase in living space, as well as habitat diversity and increased environmental stability downstream (Horwitz, 1978; Beecher et al., 1988; Oberdorff et al., 1993).

The knowledge of the ichthyo-fauna of the province of Córdoba has increased noticeably in the last few years (Haro \& Bistoni, 1996; Haro et al., 1996). Yet, the distribution of fish communities and the factors influencing this distribution are still unknown. Our main goals were to analyze the variation in fish species richness and the trophic composition along an upstream-downstream gradient and to identify the factors associated with the pattern observed in rivers of the eastern region of the province of Córdoba.

\section{MATERIALS AND METHODS}

The studied rivers were: Primero (Suquía), Segundo (Xanaes), Tercero (Calamuchita) and Cuarto (Chocancharagua) with origin in the mountain range of Sierras Grandes (Fig. 1). The first two streams are closed basins which flow into the Mar Chiquita Lake and the Tercero and Cuarto rivers are open systems connected with Paraná River (Vázquez et al., 1979).

The species richness of these lotic systems was estimated from the following papers:

1. Basin of Primero River. Data from 15 localities taken from Haro et al. (1986); Haro \& Bistoni (1994); Haro et al. (1996); Bistoni et al. (1999); Hued \& Bistoni (2001).
2. Basin of Segundo River. Data from 9 localities taken from Haro et al. (1987); Haro \& Bistoni (1994); Haro \& Bistoni (1996).

3. Basin of Tercero River. Data from 10 localities taken from Haro et al. (1996); Videla \& Bistoni (1999).

4. Basin of Cuarto River. Data from 8 localities taken from Haro et al. (1991); Haro \& Bistoni (1996).

In the above mentioned studies, fish were collected for at least a year, in all habitat types present, in order to obtain a representative sample of the fish assemblage. Fish species were captured with trawl nets, gillnets, "atarraya", handnets, fishing rods and electrofisher. The physical parameters estimated were: altitude (from 75 to $1,400 \mathrm{~m}$ above sea level), distance from source (from 4.25 to 350 $\mathrm{km}$ ) and stream order ( 1 to 5$)$. These parameters were obtained from topographic maps with a scale of 1:50,000. We determined the order of the different sections of the rivers following the Strahler Method (Boulton \& Brock, 2001).

We assigned each species to one of the five following trophic group based on its principal adult food as indicated by the literature (Destefanis \& Freyre, 1972; Ringuelet et al., 1980; Escalante, 1983, 1984; Haro \& Gutiérrez, 1985; Gutiérrez et al., 1986; Bistoni et al., 1996): Invertivores (I), Piscivores (P), Omnivores (O), LimnivoreDetrivores (L-D) and Herbivores (H). Invertivores is a general term applied to species that typically eat terrestrial and aquatic insects, little crustaceans, oligochaetes and mollusks (Oberdorff \& Hughes, 1992). Piscivores feed mainly on other fish and crabs, and on insects to a lesser degree. Omnivores consume animal and plant items in a similar proportion. The term Limnivore-Detrivore is applied to species that consume animal and/or plant material from mud or as detritus from the river bed. Herbivores refer to the species that consume primarily algae. This category was not considered in the statistical analysis because it was represented by only one species.

We related the species richness and the different trophic groups to the physical variables using the Spearman Rank Correlation Analysis. For the Principal Component Analysis (PCA) we developed the matrix according to maximum altitude, distance from source and order where each species occurs (Infostat, 2001). 


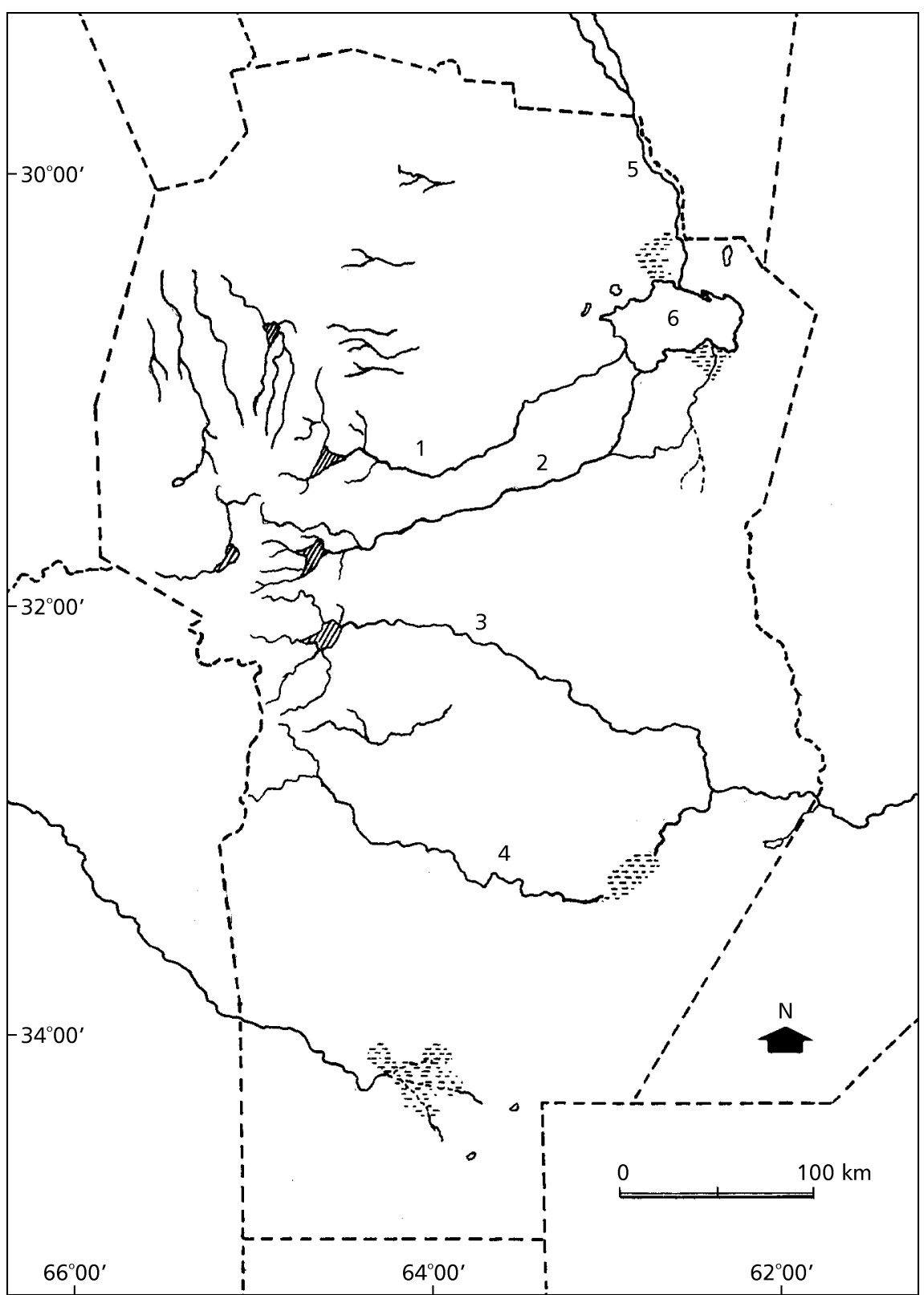

Fig. 1 - Map of the studied area showing the location of the rivers. References: 1. Primero River; 2. Segundo River; 3. Tercero River; 4. Cuarto River; 5. Dulce River; 6. Mar Chiquita Lake.

The distribution of species among trophic groups was analyzed within three altitudinal clas- ses: high (>900 m), medium (900-400 m) and low sections $(<400 \mathrm{~m})$ of the rivers. 


\section{RESULTS}

There was a pattern of low species richness in headwaters followed by an increase in richness downstream. We examined relationships between species and site characteristics (altitude, distance from source and stream order). Results obtained through the Spearman Rank Correlation Analysis indicated significant relationships between them. As expected, species richness increased significantly with increase of distance from source and stream order and decreased significantly with increase of altitude (altitude, $\mathrm{R}=-0.6809$; order, $\mathrm{R}=0.6913$; distance from source, $R=0.4915)(p<0.05)$.

Table 1 shows the fish species collected for each studied river and Table 2 shows the fish species distribution and richness according to the altitude gradient. There was a noticeable rise in species number from the interval 1,200-1,000 m and from $600 \mathrm{~m}$ downstream (Table 2). Only $O$. mykiss and B. iheringi were recorded in the upper sections of the rivers. The first species was captured from the headwater to $800 \mathrm{~m}$ downstream and the latter was present in all altitudes considered.

Communities were more complex downstream because of the presence of new species. Fifteen species were observed at the interval 1,000-1,200 $\mathrm{m}, 8$ more at $600-400 \mathrm{~m}$ and 3 more below $400 \mathrm{~m}$, totaling 29 species (Table 2).

The greatest richness occurred in the fourth order sections, with a decrease in the fifth order sections (Table 3 ). If we consider distance from source, the highest number of species occurs at $160 \mathrm{~km}$ downstream (Table 4).

The variability observed on the first component of the Principal Component Analysis is explained by the distance from source and the stream order. The trout $O$. mykiss is markedly separated from the other species because it inhabits headwater sections (Fig. 2). Those species recorded near the mouth are represented in the right part of the graph. On the second component the species are distributed along an altitudinal gradient. The two first principal components accounted for $27.14 \%$ and $15.13 \%$ of the total variance respectively (Tables 5 and 6).

Table 2 shows the classification of species into trophic categories. According to the results of the Spearman Rank Correlation Analysis, the species number of each trophic group was related significantly to the physical variables (Table 7).
They decreased with increasing altitude and increased with an increase in order and distance from source.

Table 8 shows the proportion of each trophic group in relation to the total species number of each community for three altitude intervals. The number of invertivorous species was dominant in all river sections although, its relative importance with respect to the total community decreased downstream. On the contrary, piscivores were scarcely represented in the headwaters, increasing their percentage towards the mouth. Omnivores and limnivore-detrivores richness showed no marked variation along the rivers.

\section{DISCUSSION}

Our results support the premise that the number of fish species increases along an upstreamdownstream gradient and show that changes in the fish assemblage composition of the eastern region of the province of Córdoba are associated with the watershed characteristics considered in our work.

Correspondence between fish distribution and environmental variables has been documented by several researchers (Penczak \& Man, 1990; Rahel \& Hubert, 1991; Oberdorff \& Hughes, 1992; Oberdorff \& Porcher, 1992; Barreto \& Uieda, 1998; Uieda \& Barreto, 1999) and they confirmed longitudinal changes of fish assemblages along an upriver-downriver gradient.

Individual physical factors are correlated with distribution of individual species or composition of local assemblages. However, many of these factors are interrelated. In most studies statistical approaches were used to detect individual variables that best predict fish assemblages structure with mixed results. An alternative approach is to seek patterns in fish assemblages correlated with or explained by higherorder descriptions of systems such as longitudinal zonation in stream (Matthews, 1998).

Headwater communities presented a simple structure, with only two species $O$. mykiss and $B$. iheringi. The first species was introduced in Argentina at the beginning of the twentieth century and inhabits areas near the headwaters because of its specific requirements of oxygen, $\mathrm{pH}$ and temperature (Huet, 1983). It is present only in the cool headwaters and rapidly decline in abundance a few kilometers downstream where stream temperatures are warmer (Videla \& Bistoni, 1999; Hued \& Bistoni, 2001). 
TABLE 1

Fish species richness in each studied river.

\begin{tabular}{|c|c|c|c|c|}
\hline Species & $\begin{array}{l}\text { Primero } \\
\text { river }\end{array}$ & $\begin{array}{l}\text { Segundo } \\
\text { river }\end{array}$ & $\begin{array}{c}\text { Tercero } \\
\text { river }\end{array}$ & $\begin{array}{c}\text { Cuarto } \\
\text { river }\end{array}$ \\
\hline Oncorhynchus mykiss (Walbaum, 1972) & $\mathrm{X}$ & $\mathrm{X}$ & $\mathrm{X}$ & $\mathrm{X}$ \\
\hline Oligosarcus jenynsi (Günther, 1864) & $\mathrm{X}$ & $\mathrm{X}$ & $\mathrm{X}$ & $\mathrm{X}$ \\
\hline Salminus maxillosus Valenciennes, 1840 & & & $\mathrm{X}$ & $\mathrm{X}$ \\
\hline Acrobrycon tarijae Fowler, 1941 & & & $\mathrm{X}$ & $\mathrm{X}$ \\
\hline Astyanax cordovae (Günther, 1880) & $\mathrm{X}$ & $\mathrm{X}$ & & \\
\hline Astyanax eigenmanniorum (Cope 1894) & $\mathrm{X}$ & $\mathrm{X}$ & $\mathrm{X}$ & $\mathrm{X}$ \\
\hline Astyanax fasciatus (Cuvier, 1819) & & & & $\mathrm{X}$ \\
\hline Astyanax bimaculatus Eigenmann, 1907 & $\mathrm{X}$ & $\mathrm{X}$ & & \\
\hline Bryconamericus iheringi (Boulenger, 1887) & $\mathrm{X}$ & $\mathrm{X}$ & $\mathrm{X}$ & $\mathrm{X}$ \\
\hline Cheirodon interruptus (Jenyns, 1842) & $\mathrm{X}$ & $\mathrm{X}$ & $\mathrm{X}$ & $\mathrm{X}$ \\
\hline Odontostilbe microcephala Eigenmann, 1907 & $\mathrm{X}$ & $\mathrm{X}$ & & \\
\hline Hoplias malabaricus (Bloch, 1794) & $\mathrm{X}$ & $\mathrm{X}$ & $\mathrm{X}$ & $\mathrm{X}$ \\
\hline Parodon cf. tortuosus (Eigenmann and Norris, 1900) & $\mathrm{X}$ & $\mathrm{X}$ & & \\
\hline Prochilodus platensis Holmberg, 1889 & & & $\mathrm{X}$ & $\mathrm{X}$ \\
\hline Cyphocharax boga (Henzel, 1870) & & $\mathrm{X}$ & $\mathrm{X}$ & $\mathrm{X}$ \\
\hline Cyprinus carpio (Linné, 1758) & $\mathrm{X}$ & $\mathrm{X}$ & $\mathrm{X}$ & $\mathrm{X}$ \\
\hline Heptapterus mustelinus (Valenciennes, 1840) & & $\mathrm{X}$ & $\mathrm{X}$ & \\
\hline Pimelodella laticeps Eigenmann, 1917 & $\mathrm{X}$ & $\mathrm{X}$ & $\mathrm{X}$ & $\mathrm{X}$ \\
\hline Pimelodus albicans (Valenciennes, 1840) & $\mathrm{X}$ & $\mathrm{X}$ & $\mathrm{X}$ & $\mathrm{X}$ \\
\hline Rhamdia sapo (Valenciennes, 1840) & $\mathrm{X}$ & $\mathrm{X}$ & $\mathrm{X}$ & $\mathrm{X}$ \\
\hline Trichomycterus corduvense Weyenbergh 1879 & $\mathrm{X}$ & $\mathrm{X}$ & $\mathrm{X}$ & \\
\hline Corydoras paleatus (Jenyns, 1842) & $\mathrm{X}$ & $\mathrm{X}$ & $\mathrm{X}$ & $\mathrm{X}$ \\
\hline Rineloricaria catamarcensis (Berg, 1895) & $\mathrm{X}$ & & $\mathrm{X}$ & $\mathrm{X}$ \\
\hline Hypostomus commersoni (Valenciennes, 1840) & & & & $\mathrm{X}$ \\
\hline Hypostomus cordovae (Günther, 1880) & $\mathrm{X}$ & $\mathrm{X}$ & $\mathrm{X}$ & $\mathrm{X}$ \\
\hline Jenynsia multidentata (Jenyns, 1842) & $\mathrm{X}$ & $\mathrm{X}$ & $\mathrm{X}$ & $\mathrm{X}$ \\
\hline Gambusia affinis (Baird and Girard, 1854) & $\mathrm{X}$ & $\mathrm{X}$ & $\mathrm{X}$ & \\
\hline Cnesterodon decenmaculatus (Jenyns, 1842) & $\mathrm{X}$ & $\mathrm{X}$ & $\mathrm{X}$ & $\mathrm{X}$ \\
\hline Odontesthes bonariensis (Cuvier and Valenciennes, 1835) & $\mathrm{X}$ & $\mathrm{X}$ & $\mathrm{X}$ & $\mathrm{X}$ \\
\hline Synbranchus marmoratus Bloch, 1795 & $\mathrm{X}$ & $\mathrm{X}$ & $\mathrm{X}$ & $\mathrm{X}$ \\
\hline Cichlasoma facetum (Jenyns, 1842) & $\mathrm{X}$ & $\mathrm{X}$ & $\mathrm{X}$ & $\mathrm{X}$ \\
\hline Gymnogeophagus australis (Eigenmann, 1907) & & & $\mathrm{X}$ & $\mathrm{X}$ \\
\hline
\end{tabular}


TABLE 2

Fish species distribution and richness according to the altitude gradient. It is shown the trophic group classification. References: I: Invertivorous; P: Piscivores; O: Omnivores; L-D: Limnivore-Detritivores; H:

Herbivores. 1: 1,400-1,200; 2: 1,199-1,000; 3: 999-800; 4: 799-600; 5: 599-400; 6: 399-200; 7: < 200 (meters above sea level).

\begin{tabular}{|c|c|c|c|c|c|c|c|c|}
\hline \multirow{2}{*}{ Species } & \multirow{2}{*}{$\begin{array}{l}\text { Trophic } \\
\text { group }\end{array}$} & \multicolumn{7}{|c|}{ Altitude } \\
\hline & & 1 & 2 & 3 & 4 & 5 & 6 & 7 \\
\hline O. mykiss & I & $X$ & $X$ & $\mathrm{X}$ & & & & \\
\hline B. iheringi & I & $\mathrm{X}$ & $X$ & $\mathrm{X}$ & $\mathrm{X}$ & $X$ & $X$ & $\mathrm{X}$ \\
\hline A. eigenmanniorum & I & & $\mathrm{X}$ & $\mathrm{X}$ & $\mathrm{X}$ & $\mathrm{X}$ & $\mathrm{X}$ & $\mathrm{X}$ \\
\hline C. paleatus & L-D & & $X$ & $\mathrm{X}$ & $\mathrm{X}$ & $X$ & $X$ & $\mathrm{X}$ \\
\hline H. cordovae & L-D & & $\mathrm{X}$ & $\mathrm{X}$ & $\mathrm{X}$ & $\mathrm{X}$ & $\mathrm{X}$ & $\mathrm{X}$ \\
\hline$R$. catamarcensis & L-D & & $\mathrm{X}$ & $\mathrm{X}$ & $\mathrm{X}$ & $\mathrm{X}$ & $\mathrm{X}$ & $\mathrm{X}$ \\
\hline J. multidentata & $\mathrm{O}$ & & $\mathrm{X}$ & $\mathrm{X}$ & $\mathrm{X}$ & $\mathrm{X}$ & $\mathrm{X}$ & $\mathrm{X}$ \\
\hline C. decenmaculatus & $\mathrm{O}$ & & $\mathrm{X}$ & $\mathrm{X}$ & $\mathrm{X}$ & $X$ & $\mathrm{X}$ & $\mathrm{X}$ \\
\hline R. sapo & $\mathrm{P}$ & & $\mathrm{X}$ & $\mathrm{X}$ & $\mathrm{X}$ & $X$ & $\mathrm{X}$ & $\mathrm{X}$ \\
\hline O. jenynsi & $\mathrm{P}$ & & $\mathrm{X}$ & $\mathrm{X}$ & $\mathrm{X}$ & $X$ & $\mathrm{X}$ & \\
\hline S. marmoratus & $\mathrm{P}$ & & $\mathrm{X}$ & $\mathrm{X}$ & & $\mathrm{X}$ & $\mathrm{X}$ & $\mathrm{X}$ \\
\hline C. facetum & $\mathrm{O}$ & & & $X$ & $X$ & $X$ & $X$ & $X$ \\
\hline Ch. interruptus & $\mathrm{O}$ & & $\mathrm{X}$ & & $\mathrm{X}$ & $X$ & $\mathrm{X}$ & $\mathrm{X}$ \\
\hline P. laticeps & I & & $\mathrm{X}$ & & $\mathrm{X}$ & $\mathrm{X}$ & $\mathrm{X}$ & $\mathrm{X}$ \\
\hline H. mustelinus & $\mathrm{I}$ & & & & $\mathrm{X}$ & $X$ & $X$ & $\mathrm{X}$ \\
\hline T. corduvense & I & & $\mathrm{X}$ & & $X$ & $X$ & $X$ & \\
\hline O. bonariensis & I & & & & $X$ & $X$ & $X$ & $\mathrm{X}$ \\
\hline P. cf. tortuosus & $\mathrm{H}$ & & $X$ & & $X$ & $X$ & & $\mathrm{X}$ \\
\hline H. commersoni & L-D & & & $\mathrm{X}$ & & & $\mathrm{X}$ & $\mathrm{X}$ \\
\hline P. albicans & $\mathrm{P}$ & & & & $X$ & & $X$ & $\mathrm{X}$ \\
\hline A. cordovae & $\mathrm{I}$ & & & & & $\mathrm{X}$ & $\mathrm{X}$ & $\mathrm{X}$ \\
\hline H. malabaricus & $\mathrm{P}$ & & & & & $X$ & $X$ & $\mathrm{X}$ \\
\hline C. boga & L-D & & & & & $X$ & $X$ & $\mathrm{X}$ \\
\hline G. affinis & $\mathrm{O}$ & & & & & $X$ & $X$ & $\mathrm{X}$ \\
\hline G. australis & $\mathrm{O}$ & & & & & $X$ & $X$ & $\mathrm{X}$ \\
\hline A. tarijae & $\mathrm{I}$ & & & & & $\mathrm{X}$ & $\mathrm{X}$ & $\mathrm{X}$ \\
\hline P. platensis & L-D & & & & & $\mathrm{X}$ & $\mathrm{X}$ & $\mathrm{X}$ \\
\hline C. carpio & L-D & & & & & $X$ & & $\mathrm{X}$ \\
\hline S. maxillosus & $\mathrm{P}$ & & & & & & $\mathrm{X}$ & $\mathrm{X}$ \\
\hline A. bimaculatus & $\mathrm{I}$ & & & & & & $\mathrm{X}$ & $\mathrm{X}$ \\
\hline O. microcephala & $\mathrm{O}$ & & & & & & $\mathrm{X}$ & $\mathrm{X}$ \\
\hline A. fasciatus & $\mathrm{I}$ & & & & & & & $\mathrm{X}$ \\
\hline Species richness & & 2 & 15 & 13 & 18 & 25 & 28 & 29 \\
\hline
\end{tabular}


TABLE 3

Species distribution and richness according to the stream order.

\begin{tabular}{|c|c|c|c|c|}
\hline \multirow{2}{*}{ Species } & \multicolumn{4}{|c|}{ Stream order } \\
\hline & 2 & 3 & 4 & 5 \\
\hline O. mykiss & $X$ & $\mathrm{X}$ & $X$ & \\
\hline O. jenynsi & $X$ & $\mathrm{X}$ & $\mathrm{X}$ & $X$ \\
\hline A. eigenmanniorum & $X$ & $X$ & $\mathrm{X}$ & $\mathrm{X}$ \\
\hline R. sapo & $\mathrm{X}$ & $\mathrm{X}$ & $\mathrm{X}$ & $\mathrm{X}$ \\
\hline H. cordovae & $\mathrm{X}$ & $\mathrm{X}$ & $\mathrm{X}$ & $\bar{X}$ \\
\hline C. paleatus & $\mathrm{X}$ & & $X$ & $X$ \\
\hline T. corduvense & & $\mathrm{X}$ & $\mathrm{X}$ & \\
\hline R. catamarcensis & & $X$ & $\mathrm{X}$ & \\
\hline B. iheringi & & $\mathrm{X}$ & $\mathrm{X}$ & $\mathrm{X}$ \\
\hline Ch. interruptus & & $\mathrm{X}$ & $X$ & $\mathrm{X}$ \\
\hline P. cf. tortuosus & & $\mathrm{X}$ & $\mathrm{X}$ & $\mathrm{X}$ \\
\hline P. laticeps & & $\mathrm{X}$ & $\mathrm{X}$ & $\bar{X}$ \\
\hline J. multidentata & & $\mathrm{X}$ & $X$ & $\mathrm{X}$ \\
\hline C. decenmaculatus & & $\mathrm{X}$ & $X$ & $\mathrm{X}$ \\
\hline S. marmoratus & & $X$ & $\mathrm{X}$ & $\mathrm{X}$ \\
\hline P. platensis & & & $\mathrm{X}$ & \\
\hline G. australis & & & $X$ & \\
\hline A. tarijae & & & $\mathrm{X}$ & \\
\hline S. maxillosus & & & $X$ & \\
\hline H. commersoni & & & $X$ & \\
\hline O. microcephala & & & $\mathrm{X}$ & $\mathrm{X}$ \\
\hline H. malabaricus & & & $\mathrm{X}$ & $X$ \\
\hline C. boga & & & $\mathrm{X}$ & $\mathrm{X}$ \\
\hline C. carpio & & & $\mathrm{X}$ & $\mathrm{X}$ \\
\hline H. mustelinus & & & $\mathrm{X}$ & $\mathrm{X}$ \\
\hline P. albicans & & & $\mathrm{X}$ & $\mathrm{X}$ \\
\hline A. bimaculatus & & & $\mathrm{X}$ & $\mathrm{X}$ \\
\hline O. bonariensis & & & $\mathrm{X}$ & $X$ \\
\hline C. facetum & & & $X$ & $\mathrm{X}$ \\
\hline G. affinis & & & $\mathrm{X}$ & $X$ \\
\hline A. cordovae & & & $X$ & $\mathrm{X}$ \\
\hline A. fasciatus & & & & $\mathrm{X}$ \\
\hline Richness & 6 & 14 & 31 & 24 \\
\hline
\end{tabular}


TABLE 4

Species distribution and richness according to the distance from source.

\begin{tabular}{|c|c|c|c|c|c|c|c|}
\hline \multirow{2}{*}{ Species } & \multicolumn{7}{|c|}{ Distance from source (km) } \\
\hline & $<15$ & $15-45$ & 44-75 & 74-100 & 99-130 & $129-160$ & $>160$ \\
\hline O. mykiss & $\mathrm{X}$ & $\mathrm{X}$ & & & & & \\
\hline T. corduvense & $\mathrm{X}$ & $\mathrm{X}$ & $\mathrm{X}$ & $\mathrm{X}$ & $X$ & & \\
\hline O. jenynsi & $\mathrm{X}$ & $\mathrm{X}$ & $\mathrm{X}$ & $\mathrm{X}$ & $\mathrm{X}$ & $\mathrm{X}$ & $\mathrm{X}$ \\
\hline A. eigenmanniorum & $\mathrm{X}$ & $\mathrm{X}$ & $\mathrm{X}$ & $\mathrm{X}$ & $\mathrm{X}$ & $\mathrm{X}$ & $\mathrm{X}$ \\
\hline B. iheringi & $\mathrm{X}$ & $\mathrm{X}$ & $X$ & $\mathrm{X}$ & $X$ & $\mathrm{X}$ & $\mathrm{X}$ \\
\hline Ch. interruptus & $\mathrm{X}$ & $X$ & $\mathrm{X}$ & $\mathrm{X}$ & $X$ & $\mathrm{X}$ & $\mathrm{X}$ \\
\hline P. laticeps & $X$ & $X$ & $\mathrm{X}$ & $X$ & $X$ & $\mathrm{X}$ & $\mathrm{X}$ \\
\hline H. cordovae & $\mathrm{X}$ & $\mathrm{X}$ & $\mathrm{X}$ & $\mathrm{X}$ & $\mathrm{X}$ & $\mathrm{X}$ & $\mathrm{X}$ \\
\hline J. multidentata & $\mathrm{X}$ & $X$ & $X$ & $\mathrm{X}$ & $X$ & $X$ & $X$ \\
\hline C. decenmaculatus & $\mathrm{X}$ & $X$ & $\mathrm{X}$ & $\mathrm{X}$ & $X$ & $\mathrm{X}$ & $\mathrm{X}$ \\
\hline$R$. sapo & $X$ & $X$ & $X$ & $X$ & $\mathrm{X}$ & $X$ & $X$ \\
\hline C. paleatus & $\mathrm{X}$ & $X$ & $\mathrm{X}$ & $\mathrm{X}$ & $X$ & $\mathrm{X}$ & $\mathrm{X}$ \\
\hline R. catamarcensis & $X$ & $X$ & $X$ & $X$ & $X$ & $X$ & $X$ \\
\hline P. cf. tortuosus & $X$ & $X$ & $X$ & $\mathrm{X}$ & $\mathrm{X}$ & & $\mathrm{X}$ \\
\hline S. marmoratus & $\mathrm{X}$ & $X$ & & & $X$ & $X$ & $\mathrm{X}$ \\
\hline H. mustelinus & & $X$ & $X$ & $X$ & $\mathrm{X}$ & & $\mathrm{X}$ \\
\hline C. facetum & & $X$ & & $X$ & & $X$ & $X$ \\
\hline O. bonariensis & & $\mathrm{X}$ & $\mathrm{X}$ & $\mathrm{X}$ & & $X$ & $X$ \\
\hline P. albicans & & $\mathrm{X}$ & & & & $\mathrm{X}$ & $\mathrm{X}$ \\
\hline H. commersoni & & $X$ & & & & $\mathrm{X}$ & $\mathrm{X}$ \\
\hline C. carpio & & $X$ & & & & & $\mathrm{X}$ \\
\hline G. affinis & & & & $\mathrm{X}$ & $\mathrm{X}$ & $\mathrm{X}$ & $\mathrm{X}$ \\
\hline A. tarijae & & & & $X$ & $X$ & $X$ & $\mathrm{X}$ \\
\hline A. cordovae & & & & $X$ & $X$ & $X$ & \\
\hline G. australis & & & & $X$ & $X$ & & $\mathrm{X}$ \\
\hline P. platensis & & & & $\mathrm{X}$ & & & $X$ \\
\hline H. malabaricus & & & & & $X$ & $\mathrm{X}$ & $\mathrm{X}$ \\
\hline O. microcephala & & & & & & $\mathrm{X}$ & $\mathrm{X}$ \\
\hline A. bimaculatus & & & & & & & $X$ \\
\hline S. maxillosus & & & & & & & $X$ \\
\hline A. fasciatus & & & & & & & $\mathrm{X}$ \\
\hline Richness & 15 & 21 & 15 & 22 & 21 & 21 & 29 \\
\hline
\end{tabular}




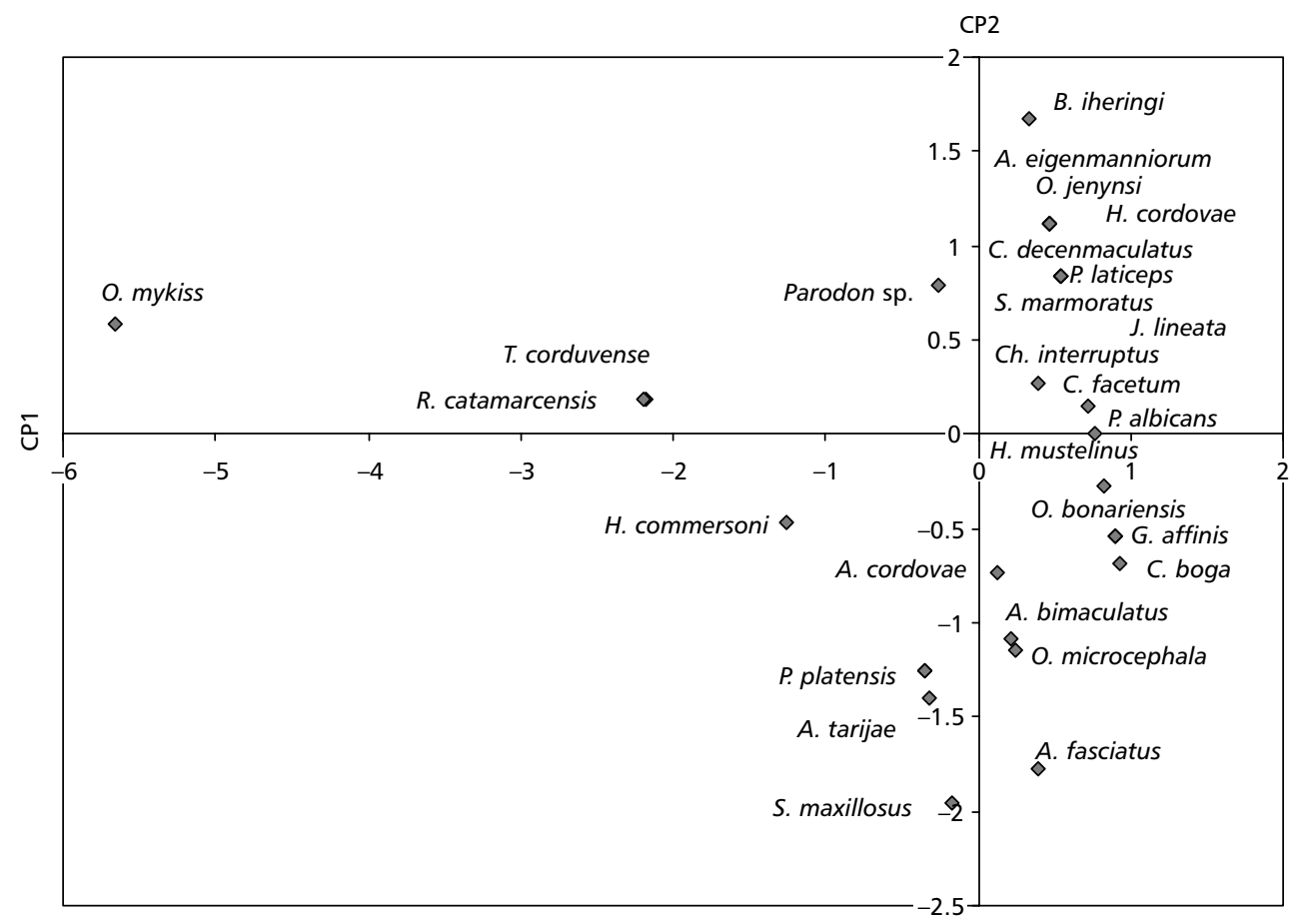

Fig. 2 - Principal Component Analysis: ordination of fish species according to the physical parameters (altitude, order and distance from source).

TABLE 5

Principal Components Analysis: eigenvalues, percentage of the total variance and accumulated percentage of the three components.

\begin{tabular}{|c|c|c|c|}
\hline Component & Eigenvalues & Percentage of variance & Accumulated percentage \\
\hline 1 & 3.528 & 27.141 & 27.141 \\
\hline 2 & 1.968 & 15.136 & 42.278 \\
\hline 3 & 1.708 & 13.136 & 55.413 \\
\hline
\end{tabular}

TABLE 6

Contribution of the physical variables to the three first axes of the Principal Component Analysis.

\begin{tabular}{|l|c|c|c|}
\hline \multirow{2}{*}{ Variables } & \multicolumn{3}{c|}{ Component } \\
\cline { 2 - 4 } & $\mathbf{1}$ & $\mathbf{2}$ & $\mathbf{3}$ \\
\hline Altitude & -0.24 & 0.95 & -0.18 \\
\hline Order & 0.67 & 0.30 & 0.68 \\
\hline Distance from source & 0.70 & 0.04 & -0.71 \\
\hline
\end{tabular}


TABLE 7

Values of Spearman Rank Correlation Analysis between trophic group and physical factors $(* p<0.05)$.

\begin{tabular}{|l|c|c|c|}
\hline \multirow{2}{*}{\multicolumn{1}{|c|}{ Trophic group }} & \multicolumn{3}{c|}{ Physical factors } \\
\cline { 2 - 4 } & Altitude & Order & Distance from source \\
\hline Invertivores & $-0.51^{*}$ & $0.61^{*}$ & $0.53^{*}$ \\
\hline Piscivores & $-0.64^{*}$ & $0.40^{*}$ & $0.65^{*}$ \\
\hline Omnivores & $-0.72^{*}$ & $0.97^{*}$ & $0.69^{*}$ \\
\hline Limnivores-detritivores & $-0.53^{*}$ & $0.40^{*}$ & $0.58^{*}$ \\
\hline
\end{tabular}

TABLE 8

Proportion of each trophic group in relation to three altitude ranks $(\mathrm{m})$.

\begin{tabular}{|l|c|c|c|}
\hline \multirow{2}{*}{\multicolumn{1}{|c|}{ Trophic group }} & \multicolumn{3}{|c|}{ Altitude } \\
\cline { 2 - 4 } & $\mathbf{> 9 0 0}$ & $\mathbf{9 0 0 - 4 0 0}$ & $<\mathbf{4 0 0}$ \\
\hline Invertivores & 42.85 & 29.63 & 33.33 \\
\hline Piscivores & 14.28 & 18.52 & 20.00 \\
\hline Omnivores & 21.43 & 25.93 & 23.33 \\
\hline Limnivores-detritivores & 21.43 & 25.93 & 23.33 \\
\hline
\end{tabular}

Records of this species at $800 \mathrm{~m}$ were occasional. Thus, headwaters can be classified as "trout zones". However, the division of rivers into zones or regions of occurrence of particular species or whole communities is of limited use, usually only for small, geographically or climatelly limited areas. This is the case of the studied headwater zones where the lower temperatures, the scarce habitat heterogeneity and the instability provoke a limited area where $O$. mykiss is the most suitable species that can tolerate these conditions. From these sites to downstream areas, fish communities changed because of the addition of other fish species. This change is so gradual that it is better to ignore "zonation" and consider that the fish assemblages change in modest increments at increasing distances downstream. Zalewski \& Naiman (1985) considered that a continuum of longitudinal change in the fish assemblage is regulated by "a continuum of abiotic and biotic factors".

The most frequently abiotic variables mentioned are an increase in habitat diversity and environmental stability (Gorman \& Karr, 1978; Schlosser, 1982). In our study, species richness increased downstream because of these factors. Stressing physico-chemical conditions are common in headwater zones, where very low temperatures and fluctuations in water flow have direct influence on the fauna, with a decrease in species richness (Schlosser, 1987; Rahel \& Hubert, 1991; Paller, 1994). A stream in a plain, with high structural diversity, has great buffering capacity: small ponds offer shelter to fishes during droughts and tend to moderate the effects of flash floods, the vegetation provides more shade and fallen trunks become substrate for bacteria, fungi and invertebrates which make up an important link in the trophic web (Karr \& Schlosser, 1977; Angermeier \& Karr, 1984). The rivers analyzed become meandering when flowing along plain zones, with numerous ponds formed by the overflow, which are very rich in species. When the altitude decreases and inverses the order increases, the stream gradient declines increasing the surface area and depth of the stream. Deep water is related to environmental stability (e.g. damping temperature variation) and allows vertical separation of microhabitats of fish species 
(Schlosser, 1987). In this way, water volume and living space increase, allowing the establishment of bigger fish. This is the case of the large flood plain lowlands and ponds, which are formed along the Cuarto River due to the gentle slope (less than 0.25\%) (Vázquez et al., 1979).

Among the species that are present at downstream areas, Hoplias malabaricus, Prochilodus platensis, Cyphocharax boga, Cyprinus carpio and Gymnogeophagus australis, aggregate in the plains from $600 \mathrm{~m}$ downstream. These species inhabit mainly large lentic zones and ponds formed by overbank flooding surrounding the main stream (Haro et al., 1996). These environments are also colonized by Gambusia affinis, a species introduced in the province (Haro \& Bistoni, 1996).

Salminus maxillosus, inhabits deep and rapidlyflowing waters, at the lower river sections. Perhaps influenced by the large floods, this species moves upstream the Tercero and Cuarto River from the Paraná River (Haro et al., 1991; Haro et al., 1996).

The fish that characterize the open systems of Tercero and Cuarto rivers (Salminus maxillosus, Acrobrycon tarijae, Prochilodus platensis, Hypostomus commersoni and Gymnogeophagus australis), are not found in the closed system of Segundo River, which is the only lotic system among the rivers analyzed that becomes of fifth order. This fact shows the difference in species richness mentioned with respect to the fourth order sections.

Astyanax bimaculatus and Odontostilbe microcephala were recorded at the mouth of the Primero and Segundo rivers. They were not captured during the first systematic surveys conducted in these rivers (Haro et al., 1986; Haro et al., 1987) but they were recorded in abundance in the Dulce River basin, which flows into the Mar Chiquita Lake (Bistoni et al., 1992). In a later work, these authors enlarged the distribution of $A$. bimaculatus and $O$. microcephala in abundance for the rivers mentioned (Haro \& Bistoni, 1994).

The Mar Chiquita Lake had a hypersaline condition (twenty-five years ago), with a mean value of $300 \mathrm{~g} / \mathrm{L}$. Later the water surface increased in size considerably, with a decrease in salinity to $30 \mathrm{~g} /$ $\mathrm{L}$, which produced a noticeable influence on the biotic communities (Reati et al., 1997). Under these mesosaline conditions, the lake is no longer a geographical barrier, and A. bimaculatus and $O$. microcephala might have colonized Primero and Segundo rivers through the Mar Chiquita Lake.
According to the results, the species number of each trophic group increased downstream but the invertivores were the dominant group in all the considered sections along the river. The trophic pattern observed, in which all groups increase in number of species towards the mouth, is due to the greater availability of ecological niches, which allows the occurrence of communities with a diversity of trophic level. This fact is directly associated with the increase in living space and habitat heterogeneity.

Acknowledgments - We specially thank R. Menni for the helpful suggestions and comments and M. Videla for her help in the data obtainment.

\section{REFERENCES}

ANGERMEIER, P. L. \& KARR, J. R., 1983, Fish communities along environmental gradient in a system of tropical streams. Env. Biol. Fish., 9: 117-135.

ANGERMEIER, P. L. \& KARR, J. R., 1984, Relationships between woody debris and fish habitat in a small warmwater stream. Trans. Amer. Fish. Soc., 113: 716-726.

BARRETO, M. G. \& UIEDA, V. S., 1998, Influence of the abiotic factors on the ichthyofauna composition in different orders stretches of Capivara River, São Paulo State, Brazil. Verh. Internat. Verein. Limnol., 26: 2180-2183.

BEECHER, H. A., DOTT, E. \& FERNAU, R., 1988, Fish species richness and stream order in Washington State streams. Env. Biol. Fish., 22: 193-209.

BISTONI, M. A., HARO, J. G. \& GUTIÉRREZ, M., 1992, Ictiofauna de los bañados del Río Dulce en la provincia de Córdoba (Argentina) (Pisces, Osteichthyes). Iheringia, Ser. Zool., 72: 105-111.

BISTONI, M. A., HARO, J. G. \& GUTIÉRREZ, M., 1996, Análisis comparativo de la dieta de Hoplias malabaricus y Salminus maxillosus (Pisces, Characidae) en los bañados del río Dulce (Córdoba, Argentina). Neotrópica, 42: 17-21.

BISTONI, M. A., HUED, A. C., VIDELA, M. \& SAGRETTI, L., 1999, Efectos de la calidad del agua sobre las comunidades ícticas de la región central de Argentina. Revista Chilena de Historia Natural, 72: 325-335.

BOULTON, A. J. \& BROCK, M. A., 2001, Australian freshwater ecology. Processes and Management. Cooperative Research Centre for Freshwater Ecology and Societas Internationalis Limnologiae, 300p.

DESTEFANIS, S. \& FREYRE, L., 1972, Relaciones tróficas de los peces de la Laguna Chascomús como un intento de referenciación ecológica y tratamiento bioestadístico del aspecto trófico. Acta Zoológica Lilloana, 29: 17-33.

ESCALANTE, A. H., 1983, Contribución al conocimiento de las relaciones tróficas de peces de agua dulce. III. Otras especies. Limnobios, 2(7): 453-463.

ESCALANTE, A. H., 1984, Contribución al conocimiento de las relaciones tróficas de peces de agua dulce. IV. Dos especies de Cichlidae y miscelánea. Limnobios, 2(8): 562-578. 
GORMAN, O. T. \& KARR, J. R., 1978, Habitat structure and stream fish communities. Ecology, 59: 507-515.

GUTIÉRREZ, M., BISTONI, M. A. \& HARO, J. G., 1986, Hábitos alimentarios de Cichlasoma facetum (Jenyns) (Pisces, Characiformes) en el Río Primero (Córdoba, Argentina). Revista de la Asociación de Ciencias Naturales del Litoral, 17(1): 115-126.

HARO, J. G. \& GUTIÉRREZ, M., 1985, Alimentación de Oligosarcus jenynsi (Günther) (Pisces, Characidae) en el Lago San Roque (Córdoba, Argentina). Revista de la Asociación de Ciencias Naturales del Litoral, 16(2): 227235.

HARO, J. G., GUTIÉRREZ, M., BISTONI, M. A., BERTOLIO, W. \& LÓPEZ, A., 1986, Ictiofauna del Río Primero (Suquía) (Córdoba, Argentina). Historia Natural, 6: 53-63.

HARO, J. G., BISTONI, M. A. \& GUTIÉRREZ, M., 1987, Ictiofauna del Río Segundo (Xanaes) (Córdoba, Argentina). Academia Nacional de Ciencias (Argentina). Miscelánea, 77: 1-13.

HARO, J. G., BISTONI, M. A. \& GUTIÉRREZ, M., 1991, Ictiofauna del Río Cuarto (Chocancharagua) (Córdoba, Argentina). Boletín Academia Nacional de Ciencias, Argentina, 59: 249-258.

HARO, J. G. \& BISTONI, M. A., 1994, Nuevas localidades para peces de la provincia de Córdoba (Argentina). Neotrópica, 40: 91-92.

HARO, J. G. \& BISTONI, M. A., 1996, Ictiofauna de la provincia de Córdoba, pp. 169-190. In: I. di Tada \& E. H. Bucher (ed.), Biodiversidad de la Provincia de Córdoba. Fauna. Córdoba, Argentina. Universidad Nacional de Río Cuarto, Córdoba, Argentina.

HARO, J. G., BISTONI, M. A. \& GUTIÉRREZ, M., 1996, Icitofauna del Río Tercero (Calamuchita) (Córdoba, Argentina). Academia Nacional de Ciencias (Argentina), Miscelánea, 96: 1-10.

HAWKES, H. A., 1975, River zonation and classification, pp. 313-374. In: B. A. Whitton (ed.), River Ecology. University of California Press, Berkeley, California, USA.

HORWITZ, R. J., 1978, Temporal variability patterns and the distributional patterns of stream fishes. Ecol. Monog., 48: $307-321$.

HUED, A. C. \& BISTONI, M. A., 2001, Ictiofauna del río San Francisco - Cosquín en la provincia de Córdoba (Argentina) (Pisces, Osteichthyes). Iheringia, Sér. Zool., 91: 75-78.

HUET, M., 1983, Tratado de piscicultura. Ed. Mundi-Prensa, Madrid, 763p.

INFOSTAT, 2001, Grupo InfoStat, Facultad de Ciencias Agropecuarias, Universidad Nacional de Córdoba, Argentina.

KARR, J. R. \& SCHLOSSER, I. J., 1977, Impact of nearstream vegetation and stream morphology on water quality and stream biota. Ecological Research, Series 600/3-77-097, Georgia.

MATTHEWS, W. J., 1998, Patterns in freshwater fish ecology. Chapman \& Hall, 756p.

OBERDORFF, T. \& HUGHES, M., 1992, Modification of an index of biotic integrity based on fish assemblages to characterize rivers of the Seine Basin, France. Hydrobiologia, 228: 117-130.
OBERDORFF, T. \& PORCHER, J., 1992, Fish assemblage structure in Brittany streams (France). Aquat. Living. Resour., 5: 215-223.

OBERDORFF, T., GUILBERT, E. \& LUCCHETTA, J., 1993, Patterns of fish richness in the Seine River basin, France. Hydrobiologia, 259: 81-91.

PALLER, M. H., 1994, Relationships between fish assemblage structure and stream order in South Carolina Coastal. Trans. Amer. Fish. Soc., 123: 150-161.

PENCZAK, T. \& MANN, R. H. K., 1990, The impact of stream order on fish populations in Pilica drainage basin, Poland. Pol. Arch. Hydrobiol., 37: 243-261.

PLATTS, W. S., 1979, Relationships among stream order, fish populations, and aquatic geomorphology in an Idaho River Drainage. Fisheries, 4: 5-9.

RAHEL, F. J. \& HUBERT, W. A., 1991, Fish assemblages and habitat gradients in a Rocky Mountain-Great Plains stream: biotic zonation and additive patterns of community change. Trans. Amer. Fish. Soc., 120: 319-332.

REATI, G. J., FLORÍN, M., FERNÁNDEZ, G. J. \& MONTES, C., 1997, The Laguna de Mar Chiquita (Córdoba, Argentina): a little known, secularly fluctuating, saline lake. International Journal of Salt Lake Research, 5: 187-219.

RINGUELET, R. A., IRIART, R. \& ESCALANTE, A. H., 1980, Alimentación del pejerrey (Basilichthys bonariensis, Atherinidae) en la Laguna Chascomús (Buenos Aires, Argentina). Relaciones Ecológicas de Complementación y Eficiencia Trófica del Plancton. Limnobios, 1: 448-460.

SCHLOSSER, I. J., 1982, Fish community structure and function along two habitat gradients in a headwater stream. Ecol. Monog., 52: 395-414.

SCHLOSSER, I. J., 1987, A conceptual framework for fish communities in small warmwater streams, pp. 17-24. In: W. J. Matthews \& D. C. Heins (ed.), Community and evolutionary ecology of North American stream fishes. University of Oklahoma Press.

UIEDA, V. S. \& BARRETTO, M. G., 1999, Composição da ictiofaua de quatro trechos de diferentes ordens do Rio Capivara, Bacia do Tietê, Botucatu, São Paulo. Rev. Bras. de Zoociências, Juiz de Fora, 1(1): 55-67.

VÁZQUEZ, J. B., LOPEZ ROBLES, A., SOSA, D. F. \& SAEZ, M. P., 1979, Aguas, pp. 139-211. In: J. B. Vázquez, R. A. Miatello \& M. E. Roque (ed.), Geografía Física de la Provincia de Córdoba. Buenos Aires, Argentina.

VIDELA, M. \& BISTONI, M. A., 1999, Composición y estructura de las comunidades ícticas de un río serrano a lo largo de un gradiente altitudinal. Iheringia, Sér. Zool., 87: 171-180.

ZALEWSKI, M. \& NAIMAN, R. J., 1985, The regulation of riverine fish communities by a continuum of abioticbiotic factors, pp. 3-9. In: J. S. Alabaster (ed.), Habitat modification and freshwater fisheries. Butterworths, London. 